\title{
PENGARUH LATIHAN ANGELED LEG PRESSED DAN LYING LEG CURLS TERHADAP EXPLOSIVE POWER OTOT TUNGKAI ATLET FUTSAL UNIVERSITAS PGRI MADIUN
}

\author{
Ardyansyah Arief Budi Utomo \\ Universitas PGRI Madiun, Indonesia \\ Email: ardyansyah@unipma.ac.id
}

Received: 28 November 2018; Accepted 8 Mei 2019; Published 13 Juni 2019

Ed 2019; 4 (1): 198-210

\begin{abstract}
ABSTRAK
Penelitian ini bertujuan untuk meneliti pengaruh latihan angeled leg pressed dan lying leg curls terhadap eksplosive power otot tungkai atlet futsal Universitas PGRI Madiun. Pendekatan pada penelitian ini adalah pendekatan kuantitatif. Jenis penelitian ini adalah penelitian eksperimen. Pada penelitian ini, peneliti menggunakan desain penelitian eksperimen randomized control group pretest-posttest. Dalam desain ini terdapat kelompok kontrol, adanya perlakuan, kemudian subjek yang digunakan ditempatkan secara acak atau random, dan adanya pretest-posttest untuk memastikan efektifitas perlakuan yang diberikan. Sampel pada penelitian ini adalah atlet futsal pada Universitas PGRI Madiun dengan jumlah 45 orang. Sampel menggunakan teknik total sampling. Instrumen menggunakan vertical jump test. Hasil penelitian ini menunjukkan meningkatnya explosive power otot tungkai atlet sebelum dan sesudah menerapkan model latihan angeled leg pressed adalah sebesar 5,16\%. Sementara peningkatan explosive power otot tungkai atlet sebelum dan sesudah menerapkan model latihan lying leg curls adalah sebesar 4,51\%. Sementara itu perbedaan pengaruh latihan angeled leg pressed dan lying leg curls terhadap eksplosive power otot tungkai atlet futsal putra di Universitas PGRI Madiun dengan nilai beda-2,26667. Dengan adanya penelitian ini, hasilnya diharapkan mampu menjadi bahan evaluasi atlet dan pelatih khususnya atlet futsal di Universitas PGRI Madiun.
\end{abstract}

Kata Kunci: Latihan; Angeled Leg Pressed; Lying Leg Curls; Eksplosive Power; Futsal

\section{THE EFFECT OF ANGLED LEG PRESSED AND LYING LEG CURLS TOWARD MUSCLE EXPLOSIVE POWER OF OF FUTSAL ATHLETES OF UNIVERSITAS PGRI MADIUN}

\begin{abstract}
This research aimed to examine the effect of angled leg pressed and lying leg curls training toward explosive limb muscle power of futsal athletes of Universitas PGRI Madiun. This research was conducted as quantitative approach which experimental design. Sample of this study were Futsal athletes of Universitas PGRI Madiun which numbered 45 male students. The instrument used was Vertical Jump test. The results of this study showed that there was improvement amount $5.16 \%$ of explosive power in of limb muscles of athletes after applying angled leg pressed training. Besides, the improvement of using explosive power of athletes' leg muscles after applying lying leg curls training was $4.51 \%$. Meanwhile, the differences effect between angled leg pressed and lying leg curls on explosive limb muscle power of male Futsal athletes at UNIPMA were -2.26667. This research result is expected to be an evaluation of athletes and coaches, especially Futsal athletes of
\end{abstract}


Universitas PGRI Madiun, in order to improve their passing skill by using angled leg pressed and lying leg curls.

Keywords: Training; Angled Leg Pressed; Lying Leg Curls; Explosive Power; Futsal

Copyright (C) 2019, Journal Sport Area

DOI: https://doi.org/10.25299/sportarea.2019.vol4(1).2366

\section{PENDAHULUAN}

Olahraga merupakan kegiatan olah tubuh atau olah fisik masyarakat sejak jaman dahulu sampai jaman sekarang, yang mana sudah banyak memberikan kontribusi dari segi peningkatan dan maintenance kesehatan sampai peningkatan perekonomian. Olahraga tidak hanya menjamah orang-orang pada strata masyarakat tingkat tinggi saja, namun pada strata masyarakat tingkat menengah sampai bawah. Dalam konteks olahraga sepakbola atau futsal, selain strategi, keterampilan bermain, dan emosional, kondisi fisik seperti otot juga perlu ditingkatkan, dalam hal ini otot yang paling dominan digunakan adalah otot tungkai, semakin kuat otot tungkai seorang pemain sepak bola, maka itu menjadi salah satu penunjang untuk dapat meraih prestasi ke arah yang lebih baik (D. W Santosa, 2015).

Urgensi penelitian dilakukan dikarenakan prestasi pada tim futsal putra Universitas PGRI Madiun menurun, ini dibuktikan dengan tidak mampunya tim tersebut memperebutkan juara dalam kompetisi-kompetisi terkini yang diadakan oleh organsisasi/klub setempat khususnya di wilayah Kota Madiun. Masalah dalam penelitian ini merupakan pembaharuan penelitian dengan yang dilakukan oleh (Putra, 2014) dengan judul "kontribusi daya ledak otot tungkai terhadap kemampuan shooting futsal pemain SMA 6 Kota Bengkulu”. Dalam penelitiannya, menghasilkan bahwa adanya hubungan yang signifikan antara power otot tungkai dengan kemampuan shooting pemain SMA Negeri 6 Kota Bengkulu. Dari penelitian Putra tersebut, kemudian peneliti mengambil tema "pengaruh latihan angeled leg pressed dan lying leg curls terhadap eksplosive power otot tungkai atlet futsal yang dilakukan pada atlet futsal putra di lingkungan Universitas PGRI Madiun.

Sebuah penelitian pengembangan yang dilakukan oleh (Ismadraga, A., Lumintiarso, 2015) dengan judul "Pengembangan model latihan "kribo" untuk power tungkai atlet lompat jauh dan sprinter SKO SMP" telah mengembangkan latihan peningkatan power otot tungkai dengan metode "Kreatif, Inovatif dengan Bola" yang dilakukan pada siswa kelas olahraga kelas IX SMP N 1 Ngawen dan SMP N 1 Playen, yang berjumlah 20 anak telah menunjukkan hasil yang baik sekali dan sangat efektif. Jika hanya dengan bola saja mampu meningkatkan power otot tungkai, maka hipotesa saya latihan menggunakan weight training akan mampu meningkatkan power otot tungkai.

Metode peningkatan otot tungkai dapat dilakukan dengan latihan konvensional maupun menggunakan weight machine dan free weight yang terdapat pada alat pusat kebugaran atau fitness (Mansur, Irianto, \& Mansur, 2018). Berdasarkan pengalaman peneliti sewaktu melatih dan mengamati beberapa tim futsal di Kota Mojokerto dan memandang bahwa umumnya proses pelatihan khususnya pada daya ledak otot tungkai dinilai kurang maksimal, sehingga prestasi yang diraih juga kurang maksimal, yang hal tersebut merupakan latar belakang masalah penelitian ini, maka peneliti mempunyai inisiatif untuk melakukan penelitian eksperimen pada pemain futsal khususnya pada atlet 
futsal Universitas PGRI Madiun. Dengan menggunakan metode peningkatan menggunakan angeled leg pressed dan lying leg curls diharapkan eksplosive power otot tungkai atlet Futsal menjadi meningkat, yang juga akan berpengaruh terhadap peningkatan prestasi dalam tim tersebut.

Pengertian latihan dalam bahasa asing biasa disebut dengan training, exercise, dan practice. Beberapa para ahli memberikan pendapatnya mengenai terminologi latihan olahraga sebagai berikut: Menurut Bompa dalam (Parulian, Gazali, \& Cendra, 2017) latihan merupakan proses pengulangan yang sistematis, progresif dengan tujuan akhir memperbaiki prestasi olahraga. Sedangkan menurut Syafruddin dalam Rasyono (2018) latihan merupakan realisasi atau implementasi dari materi atau bentuk-bentuk latihan yang telah direncanakan sebelumya, realisasi materi atau bentuk-bentuk latihan ini dilakukan secara berulang-ulang dengan tuntutan yang semakin dipersulit untuk memperbaiki kemampuan fisik dan mental. Selanjutnya menurut Hidayat dalam Rasyono (2018) tujuan utama latihan adalah untuk mengembangkan keterampilan dan performa atlet dalam usaha mencapai prestasi puncak. Dari pengertian dan tujuan latihan di atas, dapat disimpulkan bahwa latihan merupakan pelaksanaan dari materi yang dilakukan secara berulang-ulang, terprogram dan disiplin sehingga memperoleh prestasi yang maksimal.

Power merupakan salah satu komponen fisik yang harus dimiliki oleh para atlet dimana atlet harus bisa mengerahkan kekuatan secara eksplosif dalam waktu yang sesingkat-singkatnya (Ismoko \& Sukoco, 2013). Sedangkan menurut Menurut Pyke \& Watson dalam (Fenanlampir, A \& Faruq, 2015), power disebut juga sebagai kekuatan eksplosif. Menurut Santw321;oZsa (2015) daya ledak sebagai pengembangan dari kekuatan dan kecepatan banyak dijumpai dalam gerakan-gerakan dalam permainan sepakbola. Dari pendapat di atas dapat diambil kesimpulan juga bahwa power merupakan kekuatan yang super cepat.

Menurut (Munizar, Ifwandi, \& Razali, 2016) otot tungkai merupakan otot anggota gerak bawah yang terdiri dari sebagian otot serat lintang atau otot rangka. Untuk mengetahui macam-macam otot kaki, pada gambar 1 berikut akan ditampilkan gambar dan nama-nama dari otot-otot kaki manusia yang tampak pada bagian depan.

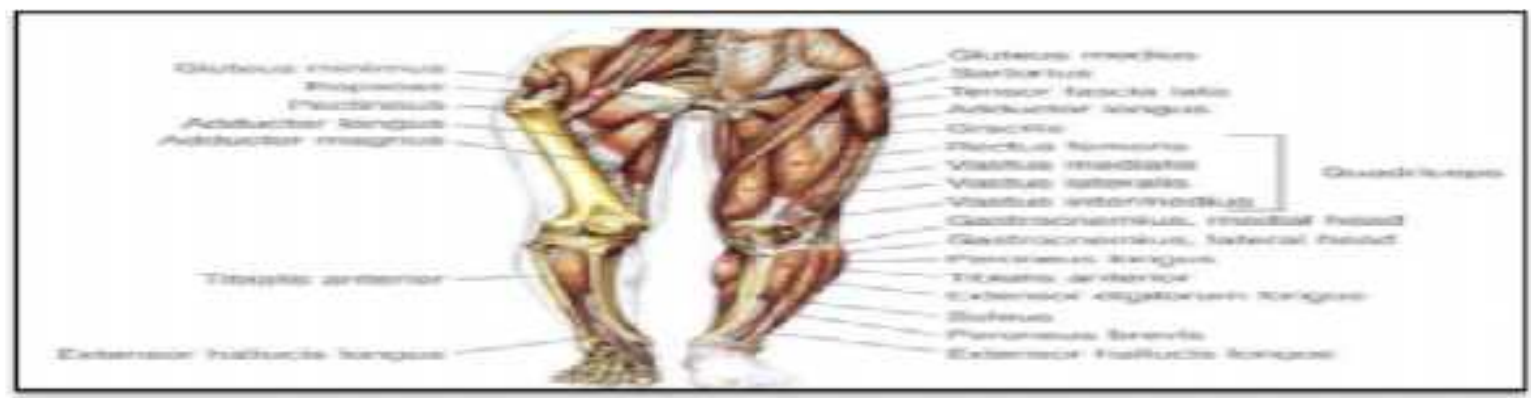

Gambar 1. Otot Kaki Tampak Depan

(Delavier, 2013)

Angeled leg pressed merupakan metode latihan weight training yang dipopulerkan oleh Delavier pada tahun 2013. Angeled leg pressed adalah salah satu bentuk latihan untuk memperkuat otot kaki dengan cara mendorong beban ke arah atas menggunakan kedua kaki pada alat leg press machine dengan sudut tertentu. SOP (Standart Operational Procedure) 
atau prosedur pelaksanaan pada latihan angeled leg pressed ini akan dijabarkan sebagai berikut:

a. Posisikan punggung sewajarnya pada sandaran punggung, dan letakkan kedua kaki pada foot plate atau bantalan kaki yang tersedia dengan posisi kaki sedikit terbuka.

b. Tarik napas dan lepaskan pengunci bar pada alat, lalu tekuk lutut secara sempurna sehingga paha menyentuh atau hampir menyentuh batang tubuh, kembali ke posisi semula disertai menghembuskan napas di akhir gerakan. Pada gambar 2 Berikut akan dipaparkan gambar angeled leg pressed.

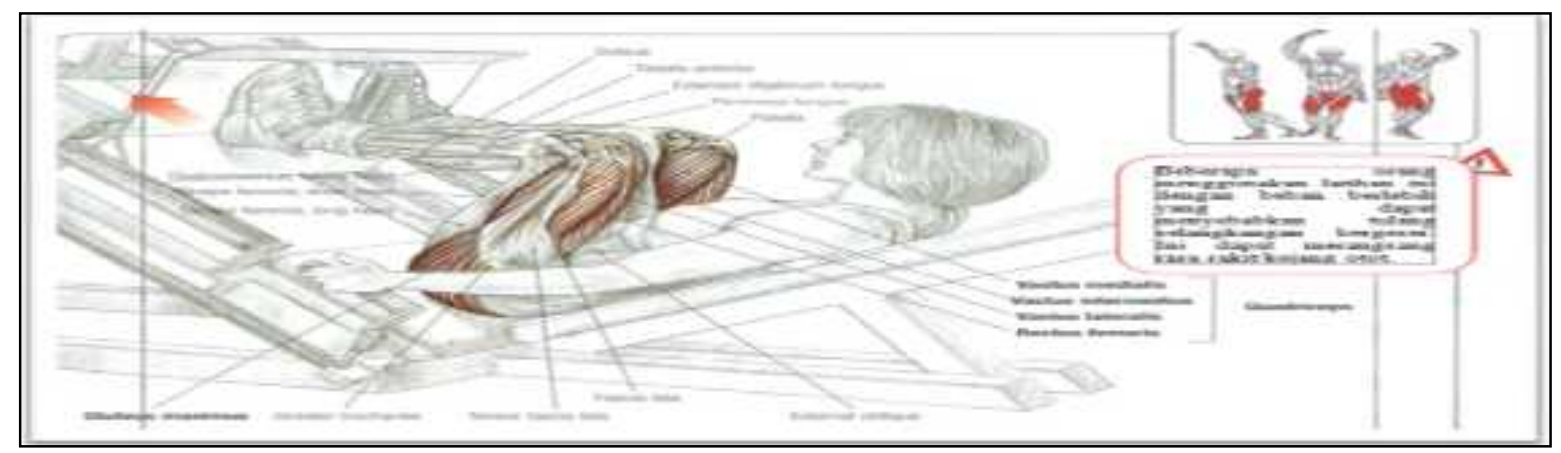

Gambar 2. Angeled Leg Pressed

(Delavier, 2013)

Sementara itu, metode latihan lying leg curls adalah salah satu bentuk latihan untuk memperkuat otot kaki sebelah belakang atas (hamstring). SOP (Standart Operational Procedure) atau prosedur pelaksanaan pada latihan lying leg curls ini akan dijabarkan sebagai berikut:

a. Berbaring telungkup di bangku leg curls, tahan handle, luruskan kaki, dan pergelangan kaki diposisikan di bawah bantalan yang tersedia pada alat.

b. Tarik napas dan tekuk kedua lutut kaki ke belakang secara bersamaan sampai tumit kaki menyentuh/hampir menyentuh pantat, kemudian hembuskan nafas di akhir gerakan, lalu kembali ke posisi semula dengan kontrol gerakan.

Untuk lebih jelasnya, pada gambar 3 berikut akan ditampilkan secara mendetail mengenai cara melakukan latihan lying leg curls sekaligus otot-otot yang berperan.

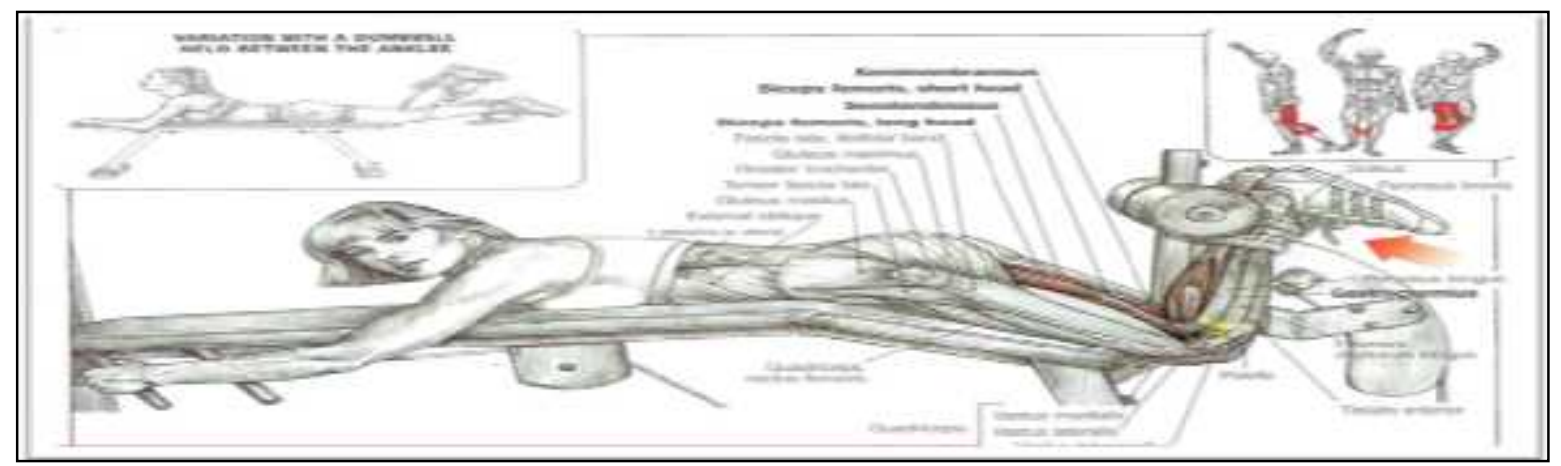

Gambar 3. Lying Leg Curls

(Delavier, 2013) 


\section{METODE PENELITIAN}

Pendekatan yang digunakan berjenis kuantitatif, sedangkan jenis penelitian ini adalah jenis penelitian eksperimen. Desain penelitian yang digunakan dalam penelitian ini adalah desain penelitian eksperimen randomized control group pretest-posttest. Dalam tabel 1 dipaparkan mengenai desain penelitian yang digunakan dalam penelitian ini.

Tabel 1. Randomized Control Group Pretest-Posttest

\begin{tabular}{ccccc}
\hline Random & Kelompok & Pretest & Treatment & Posttest \\
\hline $\mathrm{R}$ & $\mathrm{K} 1$ & $\mathrm{~T} 1$ & $\mathrm{X} 1$ & $\mathrm{~T} 2$ \\
\hline $\mathrm{R}$ & $\mathrm{K} 2$ & $\mathrm{~T} 1$ & $\mathrm{X} 2$ & $\mathrm{~T} 2$ \\
\hline $\mathrm{R}$ & $\mathrm{K} 3$ & $\mathrm{~T} 1$ & --- & $\mathrm{T} 2$ \\
\hline
\end{tabular}

(Maksum, 2012).

Keterangan:

$$
\begin{array}{ll}
\mathrm{R} & =\text { Random } \\
\mathrm{K} 1 & =\text { Kelompok angeled leg pressed } \\
\mathrm{K} 2 & =\text { Kelompok lying leg curls } \\
\mathrm{K} 3 & =\text { Kelompok kontrol } \\
\mathrm{T} 1 & =\text { Pretest } \\
\mathrm{T} 2 & =\text { Posttest } \\
\mathrm{X} 1 & =\text { Treatment angeled leg pressed } \\
\mathrm{X} 2 & =\text { Treatment lying leg curls } \\
- & =\text { Tidak ada treatment }
\end{array}
$$

Kemudian, lokasi penelitian diadakan di GOR Cendekia Universitas PGRI Madiun, Jalan Margatama I, Kota Madiun, Jawa Timur, Indonesia. Sampel yang digunakan adalah atlet futsal putra Universitas PGRI Madiun dengan jumlah mahasiswa sebanyak 45 orang. Dikarenakan jumlah populasi di bawah 100 orang, maka hal ini dijadikan dasar untuk menggunakan teknik sampling total sampling. Ini berarti keseluruhan populasi diambil sebagai sampel. Menurut Arikunto (2014) jika populasi penelitian berjumlah kurang dari 100 orang, maka akan lebih baik jika semuanya diambil. Atlet futsal yang berjumlah 45 orang berjenis kelamin laki-laki, akan dibagi menjadi 3 kelompok secara acak yang dilakukan dengan cara undian. Masing-masing kelompok baik kelompok treatment maupun kelompok kontrol berjumlah 15 orang. Kelompok 1 yaitu kelompok treatment angeled leg pressed. Kelompok 2 yaitu kelompok treatment lying leg curls. Kelompok 3 yaitu kelompok kontrol.

Instrumen atau alat ukur yang digunakan dalam penelitian ini adalah vertical jump test dengan satuan sentimeter. Setelah data mentah penelitian didapatkan, maka peneliti akan mengolah data tersebut, mulai dari menghitung skor yang diperoleh dari hasil pretest dan posttest, kemudian mencari mean, standar deviasi, varian, perbedaan peningkatan (dalam bentuk prosentase), uji normalitas data, uji homogenitas, uji t, serta anava. Semua perhitungan data statistik tersebut dihitung menggunakan software SPSS 20 For Windows. 


\section{HASIL DAN PEMBAHASAN}

Data pada penelitian ini merupakan data rasio, yang berarti data dapat diolah menggunakan statistik parametrik. Hasil analisis data dihitung secara otomatis menggunakan software IBM SPSS Statistic Versi 20 pada komputer. Berikut data deskriptif dari kelompok angeled leg pressed, kelompok lying leg curls, dan kelompok kontrol.

\section{a. Kelompok Angeled Leg Pressed}

Tabel 2. Deskriptif Statistik Kelompok Angeled Leg Pressed

\begin{tabular}{cccccc}
\hline & N & Minimum & Maximum & Mean & Std. Deviation \\
\hline Pretest & 15 & 40 & 48 & 43,33 & 2,32 \\
\hline Posttest & 15 & 42 & 50 & 45,47 & 1,959 \\
\hline Valid N (listwise) & 15 & & & & \\
\hline
\end{tabular}

Untuk memahami tabel di atas, maka pembacaan tabel di atas adalah sebagai berikut, hasil sebelum pemberian perlakuan menunjukkan angka minimum sebesar $40 \mathrm{~cm}$, angka maksimum sebesar $48 \mathrm{~cm}$, nilai mean sebesar 43,33, serta standar deviasi sebesar 2,320. Sementara itu hasil setelah pemberian perlakuan menunjukkan angka minimum sebesar 42 $\mathrm{cm}$, angka maksimum sebesar $50 \mathrm{~cm}$, nilai mean sebesar 45,47, serta standar deviasi sebesar 1,959. Pada diagram di bawah ini akan ditampilkan data pretest-posttest dengan perlakuan angeled leg pressed dalam bentuk diagram batang:

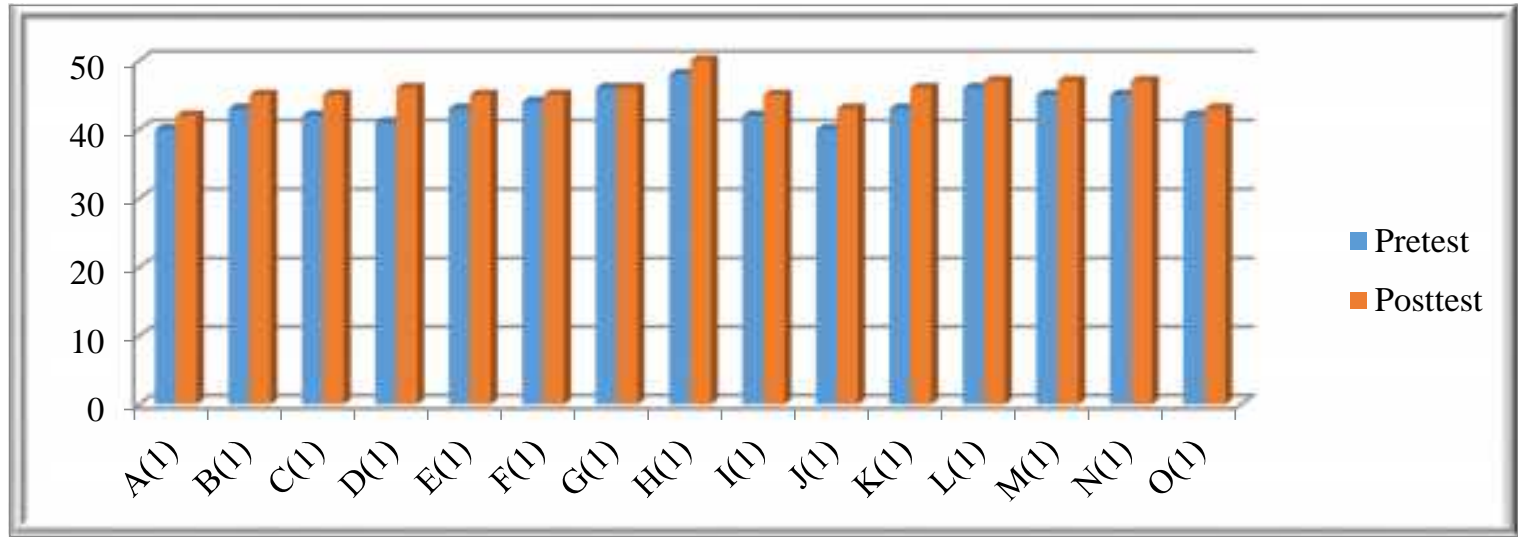

Grafik 1. Deskriptif Statistik Kelompok Angeled Leg Pressed

\section{b. Kelompok Lying Leg Curls}

Tabel 3. Deskriptif Statistik Kelompok Lying Leg Curls

\begin{tabular}{cccccc}
\hline & N & Minimum & Maximum & Mean & Std. Deviation \\
\hline Pretest & 15 & 41 & 48 & 45,67 & 1,799 \\
\hline Posttest & 15 & 44 & 52 & 47,73 & 2,086 \\
\hline Valid $N$ (listwise) & 15 & & & & \\
\hline
\end{tabular}

Untuk memahami tabel di atas, maka pembacaan tabel di atas adalah sebagai berikut, hasil sebelum pemberian perlakuan menunjukkan angka minimum sebesar $41 \mathrm{~cm}$, angka maksimum sebesar $48 \mathrm{~cm}$, nilai mean sebesar 45,67, serta standar deviasi sebesar 1,799. Sementara itu hasil setelah pemberian perlakuan menunjukkan angka minimum sebesar 44 
$\mathrm{cm}$, angka maksimum sebesar $52 \mathrm{~cm}$, nilai mean sebesar 47,73, serta standar deviasi sebesar 2,086. Di bawah ini akan ditampilkan data pretest-posttest dengan perlakuan lying leg curls dalam bentuk diagram batang:

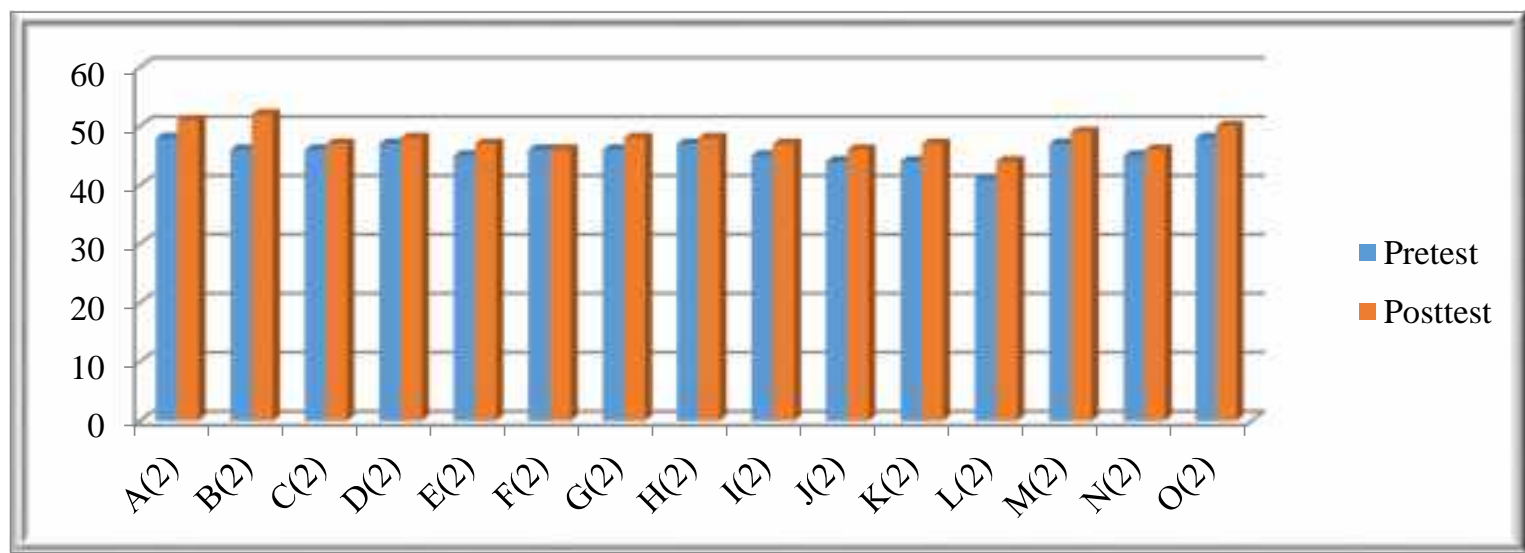

Grafik 2. Deskriptif Statistik Kelompok Angeled Leg Pressed

\section{c. Kelompok Kontrol}

Tabel 4. Deskriptif Statistik Kelompok Kontrol

\begin{tabular}{cccccc}
\hline & N & Minimum & Maximum & Mean & Std. Deviation \\
\hline Pretest & 15 & 42 & 47 & 44,73 & 1,486 \\
\hline Posttest & 15 & 43 & 50 & 46,40 & 1,844 \\
\hline Valid N (listwise) & 15 & & & & \\
\hline
\end{tabular}

Untuk memahami tabel di atas, maka pembacaan tabel di atas adalah sebagai berikut, hasil sebelum pemberian perlakuan menunjukkan angka minimum sebesar $42 \mathrm{~cm}$, angka maksimum sebesar $47 \mathrm{~cm}$, nilai mean sebesar 44,73, serta standar deviasi sebesar 1,486. Sementara itu hasil setelah pemberian perlakuan menunjukkan angka minimum sebesar 43 $\mathrm{cm}$, angka maksimum sebesar $50 \mathrm{~cm}$, nilai mean sebesar 46,40, serta standar deviasi sebesar 1,844. Di bawah ini akan ditampilkan data pretest-posttest dengan perlakuan lying leg curls dalam bentuk diagram batang:

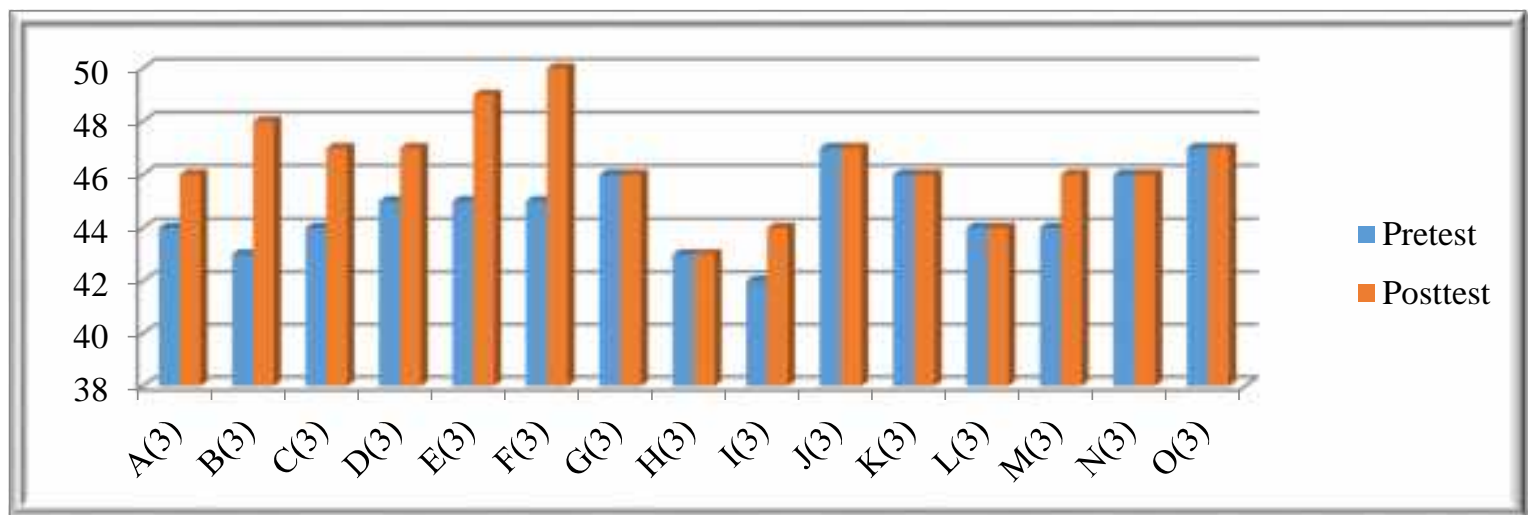

Grafik 3. Deskriptif Statistik Kelompok Kontrol 


\section{Uji Normalitas}

Uji normalitas data digunakan untuk memastikan bahwa data yang diperoleh berdistribusi normal. Uji normalitas data pada penelitian ini menggunakan uji kolmogorov smirnov yang dilakukan menggunakan software IBM SPSS Statistic Versi 20. Berikut hasil uji normalitas data:

Tabel 5. Uji Normalitas Data

\begin{tabular}{|c|c|c|c|c|c|c|c|}
\hline \multicolumn{8}{|c|}{ Tests of Normality } \\
\hline & \multirow{2}{*}{ Kelompok } & \multicolumn{3}{|c|}{ Kolmogorov-Smirnova } & \multicolumn{3}{|c|}{ Shapiro-Wilk } \\
\hline & & Statistic & df & Sig. & Statistic & df & Sig. \\
\hline \multirow{3}{*}{ Pretest } & Eksperimen_1 & ,157 & 15 & $200^{*}$ & ,958 & 15 &, 663 \\
\hline & Eksperimen_2 &, 173 & 15 & $200^{*}$ & ,906 & 15 &, 119 \\
\hline & Kontrol &, 156 & 15 & $200^{*}$ & ,951 & 15 &, 540 \\
\hline \multirow{3}{*}{ Posttest } & Eksperimen_1 & ,206 & 15 &, 087 & ,933 & 15 & ,307 \\
\hline & Eksperimen_2 &, 182 & 15 & ,192 & ,948 & 15 &, 496 \\
\hline & Kontrol & ,214 & 15 & ,063 & ,946 & 15 &, 463 \\
\hline \multicolumn{8}{|c|}{ *. This is a lower bound of the true significance. } \\
\hline \multicolumn{8}{|c|}{ a. Lilliefors Significance Correction } \\
\hline
\end{tabular}

Untuk menyatakan bahwa data tersebut berdistribusi normal adalah apabila nilai signifikansi lebih besar dari 5\% atau $(\alpha=0,05)$. Merujuk pada hasil analisis data pada uji Kolmogorov-Smirnov di atas, menunjukkan bahwa pada kelompok angeled leg pressed pvalue sebesar 0,200 (pretest) dan 0,087 (posttest); kelompok lying leg curls p-value sebesar 0,200 (pretest) dan 0,192 (posttest); kelompok kontrol p-value sebesar 0,200 (pretest) dan 0,663 (posttest). Kesimpulannya adalah data berdistribusi normal, karena data hitung lebih besar dari 0,05 atau $5 \%$.

\section{Uji Homogenitas}

Uji homogenitas digunakan untuk memperlihatkan bahwa dua atau lebih kelompok data sampel berasal dari populasi yang mempunyai variansi yang sama. Dalam tabel 6 akan dipaparkan mengenai hasil perhitungan uji homogenitas.

Tabel 6. Uji Homogenitas

\begin{tabular}{cccc}
\hline \multicolumn{4}{c}{ Test of Homogenity of Variances } \\
\hline \multicolumn{4}{c}{ Skor Vertical Jump } \\
\hline Levene Statistic & df1 & df2 & Sig. \\
\hline, 122 & 2 & 42 &, 885 \\
\hline
\end{tabular}

Untuk menyatakan bahwa data tersebut homogen adalah jika nilai signifikansi pada kolom (sig) menunjukkan nilai di atas 5\% atau 0,05. Berdasarkan hasil tabel di atas, nilai signifikansi pada kolom (sig) menunjukkan nilai 0,885 yang berarti 0,085 >0,05, maka dapat diambil kesimpulan bahwa data tersebut bersifat homogen. 


\section{Uji Hipotesis}

Uji hipotesis digunakan untuk menguji dugaan sementara atau pernyataan awal peneliti. Instrumen yang digunakan adalah paired t test (uji t sampel berpasangan) dan one way anova (anova satu jalur).

\section{Paired T Test}

Paired t test dipergunakan untuk menghitung nilai beda dari peningkatan explosive power otot tungkai atlet futsal sebelum dan sesudah mendapatkan perlakuan. Penghitungan paired t test dikerjakan menggunakan software SPSS versi 20 pada komputer. Terdapat 2 hipotesis yang diajukan pada masing-masing kelompok yaitu:

1) Hipotesis kelompok perlakuan metode latihan angeled leg pressed

Ho: Tidak adanya perbedaan explosive power otot tungkai sebelum dan sesudah pemberian perlakuan angeled leg pressed.

H1: Adanya perbedaan explosive power otot tungkai sebelum dan sesudah pemberian perlakuan angeled leg pressed.

2) Hipotesis kelompok perlakuan metode latihan lying leg curls

Ho: Tidak adanya perbedaan explosive power otot tungkai sebelum dan sesudah pemberian perlakuan lying leg curls.

$\mathrm{H}_{1}$ : Adanya perbedaan explosive power otot tungkai sebelum dan sesudah pemberian perlakuan lying leg curls.

Untuk mengetahui hasil penghitungan paired t test (uji t sampel berpasangan), berikut akan dipaparkan pada tabel 7.

Tabel 7. Paired T Test

\begin{tabular}{|c|c|c|c|c|c|c|c|c|c|}
\hline & & \multicolumn{5}{|c|}{ Paired Differences } & \multirow{3}{*}{$\mathbf{t}$} & \multirow{3}{*}{ df } & \multirow{3}{*}{$\begin{array}{l}\text { Sig. (2- } \\
\text { tailed) }\end{array}$} \\
\hline & & \multirow[t]{2}{*}{ Mean } & \multirow[t]{2}{*}{$\begin{array}{c}\text { Std. } \\
\text { Deviation }\end{array}$} & \multirow{2}{*}{$\begin{array}{l}\text { Std. } \\
\text { Error } \\
\text { Mean }\end{array}$} & \multicolumn{2}{|c|}{$\begin{array}{c}\text { 95\% Confidence } \\
\text { Interval of the } \\
\text { Difference } \\
\end{array}$} & & & \\
\hline & & & & & Lower & Upper & & & \\
\hline $\begin{array}{c}\text { Pair } \\
1 \\
\end{array}$ & $\begin{array}{l}\text { Pre_ALP - } \\
\text { Post_ALP }\end{array}$ & $\begin{array}{c}- \\
2,13333 \\
\end{array}$ & 1,18723 & 0,30654 & $-2,7908$ & $\begin{array}{c}- \\
1,47587 \\
\end{array}$ & $\begin{array}{c}- \\
6,96\end{array}$ & 14 & 0 \\
\hline $\begin{array}{c}\text { Pair } \\
2\end{array}$ & $\begin{array}{l}\text { Pre_LLC - } \\
\text { Post_LLC }\end{array}$ & $\begin{array}{c}- \\
2,06667\end{array}$ & 1,38701 & 0,35813 & $\begin{array}{c}- \\
2,83477 \\
\end{array}$ & $\begin{array}{c}- \\
1,29856 \\
\end{array}$ & $\begin{array}{c}- \\
5,77 \\
\end{array}$ & 14 & 0 \\
\hline
\end{tabular}

Tabel 7 di atas merupakan hasil penghitungan menggunakan software SPSS versi 20 pada komputer. Esensi yang dapat diambil dari tabel di atas ialah:

1. Perbedaan explosive power otot tungkai pada kelompok angeled leg pressed (ALP) menunjukkan nilai hitung $=0,000<\mathrm{sig}=0,05$. Dapat diputuskan bahwa $\mathrm{H}_{1}$ diterima dan $\mathrm{H}_{0}$ ditolak. Atau dapat diambil kesimpulan bahwa terdapat perbedaan explosive power otot tungkai sebelum dan sesudah pemberian perlakuan angeled leg pressed.

2. Perbedaan explosive power otot tungkai pada kelompok lying leg curls (LLC) menunjukkan nilai hitung $=0,000<\mathrm{sig}=0,05$. Dapat diputuskan bahwa $\mathrm{H}_{1}$ diterima dan $\mathrm{H}_{0}$ ditolak. Atau dapat diambil kesimpulan bahwa terdapat perbedaan explosive power otot tungkai sebelum dan sesudah pemberian perlakuan lying leg curls. 
Penghitungan persentase menunjukkan bahwa perbedaan peningkatan rata-rata pada kelompok eskperimen angeled leg pressed sebelum dan sesudah pemberian perlakuan adalah sebesar 5,16 \%. Penghitungan persentase menunjukkan bahwa perbedaan peningkatan rata-rata pada kelompok eskperimen lying leg curls sebelum dan sesudah pemberian perlakuan adalah sebesar $4,51 \%$

\section{One Way Anova}

Uji one way anova (anova satu jalur) dipergunakan untuk menghitung nilai beda explosive power otot tungkai antara kelompok yang diberi perlakuan angeled leg pressed, perlakuan lying leg curls, dan kelompok kontrol. Hipotesis yang bisa diambil adalah sebagai berikut:

$\mathrm{H}_{0} \quad$ : Tidak adanya perbedaan antara kelompok

$\mathrm{H}_{1} \quad$ : Minimal ada satu pasang kelompok yang berbeda.

Untuk mengetahui hasil penghitungan one way anova, berikut akan dipaparkan pada tabel 8 .

Tabel 8. One Way Anova

\begin{tabular}{cccccc}
\hline \multicolumn{5}{c}{ ANOVA } \\
\hline & \multicolumn{5}{c}{ All Posttest } \\
\hline & Sum of Squares & df & Mean Square & F & Sig. \\
\hline Between Groups & 38,933 & 2 & 19,467 & 5,039 &, 011 \\
\hline Within Groups & 162,267 & 42 & 3,863 & & \\
\hline Total & 201,200 & 44 & & & \\
\hline
\end{tabular}

Analisis dari hasil penghitungan tabel di atas, dapat diambil keputusan bahwa $\mathrm{H}_{1}$ diterima dan $\mathrm{H}_{0}$ ditolak. Atau dapat disimpulkan bahwa minimal ada satu pasang kelompok yang mempunyai nilai beda. Karena nilai sig $(p$ value $)=0,011<0,05$. Sementara itu, untuk mengetahui perbedaan pasangan di antara masing-masing kelompok, maka analisis data dilanjutkan dengan menggunakan uji perbandingan berganda pada SPSS dengan uji Post Hoc Multiple Comparisons.

Tabel 9. Post Hoc Multiple Comparisons Dependent Variable: All_Posttest (Eksplosif Power Otot Tungkai) LSD

\begin{tabular}{|c|c|c|c|c|c|c|}
\hline \multirow{2}{*}{$\begin{array}{c}\text { (I) } \\
\text { Kelompok }\end{array}$} & \multirow{2}{*}{$\begin{array}{c}(\mathbf{J}) \\
\text { Kelompok }\end{array}$} & \multirow{2}{*}{$\begin{array}{c}\text { Mean } \\
\text { Difference } \\
\text { (I-J) }\end{array}$} & \multirow{2}{*}{$\begin{array}{l}\text { Std. } \\
\text { Error }\end{array}$} & \multirow[b]{2}{*}{ Sig. } & \multicolumn{2}{|c|}{$95 \%$ Confidence Interval } \\
\hline & & & & & Lower Bound & Upper Bound \\
\hline \multirow{2}{*}{$\begin{array}{c}\text { Angeled } \\
\text { Leg } \\
\text { Pressed }\end{array}$} & $\begin{array}{l}\text { Lying Leg } \\
\text { Curls }\end{array}$ & $-2,26667^{*}$ & 0,71773 & 0,003 & $-3,7151$ & $-0,8182$ \\
\hline & Kontrol & $-0,93333$ & 0,71773 & 0,201 & $-2,3818$ & 0,5151 \\
\hline \multirow{2}{*}{$\begin{array}{l}\text { Lying Leg } \\
\quad \text { Curls }\end{array}$} & $\begin{array}{c}\text { Angeled Leg } \\
\text { Pressed }\end{array}$ & $2,26667^{*}$ & 0,71773 & 0,003 & 0,8182 & 3,7151 \\
\hline & Kontrol & 1,33333 & 0,71773 & 0,07 & $-0,1151$ & 2,7818 \\
\hline \multirow{2}{*}{ Kontrol } & $\begin{array}{c}\text { Angeled Leg } \\
\text { Pressed }\end{array}$ & 0,93333 & 0,71773 & 0,201 & $-0,5151$ & 2,3818 \\
\hline & $\begin{array}{l}\text { Lying Leg } \\
\quad \text { Curls }\end{array}$ & $-1,33333$ & 0,71773 & 0,07 & $-2,7818$ & 0,1151 \\
\hline
\end{tabular}


1. Pengujian perbandingan kelompok angeled leg pressed vs kelompok lying leg curls dengan hasil $p$ value $=0,003<u=0,05$. Kesimpulannya adalah terdapat perbedaan yang signifikan antara kelompok angeled leg pressed dan kelompok lying leg curls dengan nilai beda $-2,26667$.

2. Pengujian perbandingan kelompok angeled leg pressed vs kelompok kontrol dengan hasil $p$ value $=0,201>u=0,05$. Kesimpulannya adalah bahwa tidak terdapat perbedaan antara kelompok angeled leg pressed dan kelompok kontrol dengan nilai beda ,- 93333 .

3. Pengujian perbandingan kelompok lying leg curls vs kelompok kontrol dengan hasil $p$ value $=0,070>u=0,05$. Kesimpulannya adalah bahwa tidak terdapat perbedaan yang signifikan antara kelompok lying leg curls dan kelompok kontrol dengan nilai beda 1,33333 .

Pada nomor 1, pengujian hipotesis di atas menunjukkan bahwa terdapat perbedaan explosive power otot tungkai secara signifikan antara kelompok yang diberikan perlakuan dengan metode angeled leg pressed dan lying leg curls. Pada nomor 2, tidak terdapat perbedaan explosive power otot tungkai antara yang diberikan treatment angeled leg pressed dengan kelompok kontrol. Sementara itu pada kesimpulan terakhir yakni tidak terdapat perbedaan yang signifikan antara kelompok eksperimen treatment lying leg curls dan kelompok kontrol pada atlet futsal putra Universitas PGRI Madiun.

Perlakuan dengan menggunakan weight training yang dilakukan pada penelitian ini mampu meningkatkan explosive power otot tungkai, hal ini serupa dengan pernyataan (Mansur et al., 2018) "program latihan peningkatan otot yang paling efektif adalah program latihan memakai beban atau weight training program". Penelitian terdahulu yang sesuai dengan penelitian ini adalah penelitian dari (Karyono, 2016) dengan judul penelitian "Pengaruh metode latihan dan power otot tungkai terhadap kelincahan bulutangkis" dengan hasil penelitian yang menyebutkan bahwa ada perbedaan pengaruh latihan beban dan latihan plyometrik terhadap kelincahan bulutangkis dan juga penelitian dari (Wirth, Keiner, Hartmann, Sander, \& Mickel, 2016) dengan judul "Effect of 8 Weeks of Free Weight and Machine-Based Strength Training on Strength and Power Performance"

Latihan beban memberikan dampak tegangan pada otot, dan kontraksi yang sistematis, latihan beban sama dengan merusak otot (Archer, 2016), dalam artian sel-sel otot yang lama akan tergantikan dengan sel-sel otot yang baru dan mempunyai komposisi serat otot yang lebih banyak, dan otot tersebut berkembang ketika dalam keadaan istirahat setelah dilakukannya latihan, dengan bertambahnya serat-serat otot yang baru tadi, maka massa otot juga akan semakin bertambah, dan mengakibatkan kekuatan otot semakin bertambah pula. Hal inilah yang menjadi dasar mengapa weight training mampu meningkatkan power atau kekuatan seseorang.

Hal ini didukung dengan pernyataan (Sucipto \& Widiyanto, 2016) yang menyebutkan bahwa, hypertrophy adalah pertumbuhan massa otot yang menyebabkan serabut otot bertambah besar atau tebal. Menurut (Munizar et al., 2016) selama terjadi hypertrophy, sintesis protein kontraktil otot berlangsung lebih cepat dari penghancurannya, sehingga menghasilkan jumlah filament aktin dan myosin bertambah banyak dalam myofibril. 
Myofibril sendiri akan memecah dalam serabut otot untuk membentuk myofibril yang baru, hal ini yang disebut hypertrophy otot.

Penelitian dengan memberikan treatment merupakan cara untuk memanipulasi hasil latihan ke arah yang lebih baik, hal ini didukung dengan penelitian yang dilakukan oleh (Mansur, 2016) dengan judul penelitian "Pengaruh complex training manipulation terhadap peningkatan power otot tungkai pada mahasiswa Prodi PKO FIK UNY". Penelitiannya membuktikan bahwa dengan memanipulasi metode latihan pada mahasiswa Prodi PKO FIK UNY dengan peningkatan rata-rata sebesar 1,3\%, maka metode latihan ini dapat digunakan untuk meningkatkan power otot tungkai.

\section{KESIMPULAN}

Dari hasil penelitian ini, dapat ditarik beberapa kesimpulan bahwa pada treatment pertama dapat disimpulkan bahwa terdapat perbedaan eksplosive power otot tungkai atlet futsal putra Universitas PGRI Madiun sebelum dan sesudah perlakuan menggunakan angeled leg pressed. Sedangkan pada treatment kedua dapat disimpulkan bahwa terdapat perbedaan eksplosive power otot tungkai atlet futsal putra Universitas PGRI Madiun sebelum dan sesudah perlakuan menggunakan lying leg curls. Peningkatan explosive power otot tungkai atlet sebelum dan sesudah menerapkan treatment angeled leg pressed adalah sebesar 5,16\%. Sementara peningkatan explosive power otot tungkai atlet sebelum dan sesudah menerapkan treatment lying leg curls adalah sebesar 4,51\%. Sementara itu pengaruh latihan angeled leg pressed dan lying leg curls terhadap eksplosive power otot tungkai atlet futsal putra di Universitas PGRI Madiun menghasilkan nilai beda -2,26667.

\section{DAFTAR PUSTAKA}

Archer, D. C. (2016). Effects of Short-Term Jump Squat Training With and Without Chains on Strength and Power in Recreational Lifters, 4(4), 0-6. https://doi.org/10.7575/aiac.ijkss.v.4n.4p.18

Arikunto, S. (2010). Prosedur Penelitian Suatu Pendekatan Praktik. Jakarta: Rineka Cipta.

Arikunto, S. (2014). Prosedur Penelitian Suatu Pendekatan Praktik. Jakarta: Rineka Cipta.

Delavier, F. (2013). Strenght Training Anatomy. USA: Human Kinetics.

Fenanlampir, A \& Faruq, M. M. (2015). Tes dan Pengukuran dalam Olahraga. Yogyakarta: CV Andi Offset.

Ismadraga, A., Lumintiarso, R. (2015). Pengembangan Model Latihan "Kribo" Untuk Power Tungkai Atlet Lompat Jauh dan Sprinter SKO SMP. Jurnal Keolahragaan, 3(April), 16-28.

Ismoko, A. P., \& Sukoco, P. (2013). Pengaruh Metode Latihan dan Koordinasi Terhadap Power Tungkai Atlet Bola Voli Junior Putri. Jurnal Keolahragaan, 1(1), 1-12. 
Karyono, T. (2016). Pengaruh Metode Latihan dan Power Otot Tungkai Terhadap Kelincahan Bulutangkis. Jurnal Olahraga Prestasi, 12(1), 49-62.

Maksum, A. (2012). Metodologi Penelitian Dalam Olahraga. Surabaya: Unesa University Press.

Mansur. (2016). Pengaruh Complex Training Manipulation Terhadap Peningkatan Power Otot Tungkai Pada Mahasiswa Prodi PKO FIK UNY. Jurnal Olahraga Prestasi, 12(1), 16-26.

Mansur, L. K., Irianto, J. P., \& Mansur, M. (2018). Pengaruh Latihan Squat Menggunakan Free Weight dan Gym Machine Terhadap Kekuatan, Power dan Hypertrophy Otot. Jurnal Keolahragaan, 6(2), 150-161.

Munizar, Ifwandi, \& Razali. (2016). Kontribusi Power Otot Tungkai dan Power Otot Lengan Terhadap Pukulan Smash Pada Pemain Bola Voli Club Himadirga FKIP Unsyiah. Jurnal Ilmiah Mahasiswa Pendidikan Jasmani, Kesehatan Dan Rekreasi Fakultas Keguruan dan Ilmu Pendidikan Unsyiah, 2(1), 26-38.

Parulian, T., Gazali, N., \& Cendra, R. (2017). Pengaruh Metode Latihan Interval Ekstensif dan Interval Intensif Terhadap Kapasitas Vo2maksimal Pada Pemain Sepakbola SSB Tunas Harapan U-18 Pekanbaru. Seminar Nasional Olahraga 2017: Peran Pendidikan Jasmani dalam Meningkatkan Kualitas Hidup dan Karakter Bangsa (pp. 160-169).

Putra, S. (2014). Kontribusi Daya Ledak Otot Tungkai Terhadap Kemampuan Shooting Futsal Pemain SMA 6 Kota Bengkulu. Universitas Bengkulu.

Rasyono. (2018). Pengaruh Latihan Beban Karet Terhadap Peningkatan Kecepatan Tendangan Dollyo Chagi Atlet Junior Taekwondo. Journal Sport Area, 3(2), 157-167.

Santosa, D. W. (2015). Pengaruh Pelatihan Squat Jump Dengan Metode Interval Pendek Terhadap Daya Ledak (Power) Otot Tungkai. Jurnal Kesehatan Olahraga, 3(1), 158164.

Santosa, D. W. (2015). Pengaruh Pelatihan Squat Jump Dengan Metode Interval Pendek Terhadap Daya Ledak (Power) Otot Tungkai. Jurnal Kesehatan Olahraga, 3(1), 158164.

Sucipto, E., \& Widiyanto. (2016). Pengaruh Latihan Beban dan Kekuatan Otot Terhadap Hypertrophy Otot dan Ketebalan Lemak. Jurnal Keolahragaan, 4(1), 111-121.

Wirth, K., Keiner, M., Hartmann, H., Sander, A., \& Mickel, C. (2016). Effect of 8 Weeks of Free-Weight and Machine-Based Strength Training on Strength and Power Performance, 53(September), 201-210. https://doi.org/10.1515/hukin-2016-0023 